\title{
FACTORS AFFECTING THE APPEARANCE AND PERSISTENCE OF VISIBLE CUTANEOUS REACTIVE HYPEREMIA IN MAN ${ }^{1}$
}

\author{
By W. F. GREENWOOD,2 A. C. BARGER, J. R. DiPALMA, J. STOKES, III, AND \\ L. H. SMITH ${ }^{3}$
}

(From the Department of Physiology, Harvard Medical School, Boston)

(Received for publication October 7, 1947)

Changes in cutaneous reactive hyperemia have been used successfully to identify certain local $(1,2)$ and general $(3$ to 5$)$ abnormalities of the circulation. More recently it has been observed that cutaneous reactive hyperemia is altered conspicuously in normal subjects by vigorous exercise, particularly as the circulatory stress of exhaustion appears (6). Under these conditions venous pressure, cutaneous blood flow, and skin temperature were changing simultaneously and rapidly. Hence it was difficult to understand the mechanism by which cutaneous reactive hyperemia may be altered without more information on the factors which modify it in the normal subject under experimental conditions.

This account describes the effects of environmental temperature, skin temperature, elevation of the arm, venous pressure, external pressure and epinephrine iontophoresis, on the appearance and persistence of visible cutaneous reactive hyperemia. It indicates certain factors which should be kept constant when reactive hyperemia is used as a test to identify changes in cutaneous circulation.

\section{METHODS}

Cutaneous reactive hyperemia was produced locally on the horizontal volar surface of the forearm by placing a weighted plastic ring on the skin for sufficient time to produce, after removal of the ring, a distinct annular redness of the skin as described by DiPalma et al. (7). The plastic ring itself had an outer diameter of $3.5 \mathrm{~cm}$., an inner diameter of $2.5 \mathrm{~cm}$., and a total surface area of 5 sq. $\mathrm{cm}$. It was attached to the under surface of a 500 gm. weight. When resting freely on the skin the weight applied to the skin immediately beneath the ring a pressure equivalent to $73 \mathrm{~mm}$. $\mathrm{Hg}$, i.e., sufficient to collapse

\footnotetext{
1 The expenses of this investigation were defrayed in part by a grant from the Life Insurance Medical Research Fund.

2 Alexander McPhedran Fellow from the Department of Medicine, University of Toronto.

${ }^{3}$ Student Research Fellow, Life Insurance Medical Research Fund.
}

the minute vessels and to arrest blood flow (8). Direct observations through the transparent ring showed that the skin was completely blanched by this pressure. In this account the definitions and criteria described by DiPalma et al. (7) will be followed.

"Threshold time" or "threshold" is the least duration of application in seconds required to produce a complete hyperemic ring having a width equal to the surface of the plastic ring. Applications lasting less than "threshold time" produced no visible hyperemia or a patchy incomplete area of hyperemia which was either narrower or broader than the ring itself. The end point is undeniably subjective and its estimation requires certain practice, but with experience, and under constant conditions, readings can be duplicated within plus or minus 20 per cent over periods of several hours. This subjective element was finally reduced to a minimum by having one observer make readings without knowing the exact duration of the preceding occlusion, the latter being recorded by a second observer. The juxtaposition of normal skin just inside and outside the ring of hyperemia made comparisons simpler, more quantitative and more rapid than was possible with the earlier method of Lewis and Grant (1, 9 ), in which the color of one forearm had to be compared with that of the opposite forearm.

"Clearing time" is defined (7) as the time, in seconds, for complete disappearance of that reactive hyperemia which has been produced by an occlusion of threshold duration. Repeated readings of clearing time over short periods usually agreed within plus or minus 25 per cent, but occasionally varied more widely. For this reason it was found impossible to attribute as much significance to single estimations of clearing time as to single determinations of threshold.

Uniform lighting, with minimum heating, was obtained by using either (a) large 40-watt "Daylight" fluorescent bulbs at a distance to illuminate the whole forearm or (b) two small 4-watt bulbs, 5 inches long, one on each side of the forearm under reflectors.

Environmental temperature was kept constant in most observations to within $\pm 0.5^{\circ} \mathrm{C}$. by using a constant temperature room. Skin temperatures were measured by means of iron-constantan silver-soldered thermal junctions. The thermal junctions were at first applied under adhesive tape, which covered the junction, but later a springy celluloid mounting was found more satisfactory because the adhesive tape then covered only the wires leading to the junctions while the junctions themselves rested against the skin without any covering. 
Venous pressure was elevated in the forearm by means of a wide $(15 \mathrm{~cm}$.) pneumatic cuff, containing a rubber bag long enough to encircle the upper arm completely. Instantaneous inflation was assured by connecting the pneumatic cuff to a large reservoir of air, previously brought to the desired pressure. Direct readings of venous pressure in several instances verified the equality of venous pressure and pressure in the pneumatic cuff.

\section{OBSERVATIONS}

I. Comparison of gross reactive hyperemia (Lewis and Grant, [9]), with localized reactive hyperemia (DiPalma et al., [2])

Lewis and Grant (9) observed that occluding the circulation to the entire forearm for one or more minutes produced a reactive hyperemia which persisted, after release of the circulation, for a period of one-half to two-thirds the duration of the occlusion. Thus occlusion for one minute produced a reactive hyperemia which persisted visually for 40 to 65 seconds, and plethysmographically for about 25 seconds. It is interesting that for both brief and prolonged occlusions, the visible redness of the skin appeared to be a more sensitive indicator of persisting mild reactive hyperemia than the plethysmographic measurement of total forearm volume, which included the vessels of both muscle and skin.

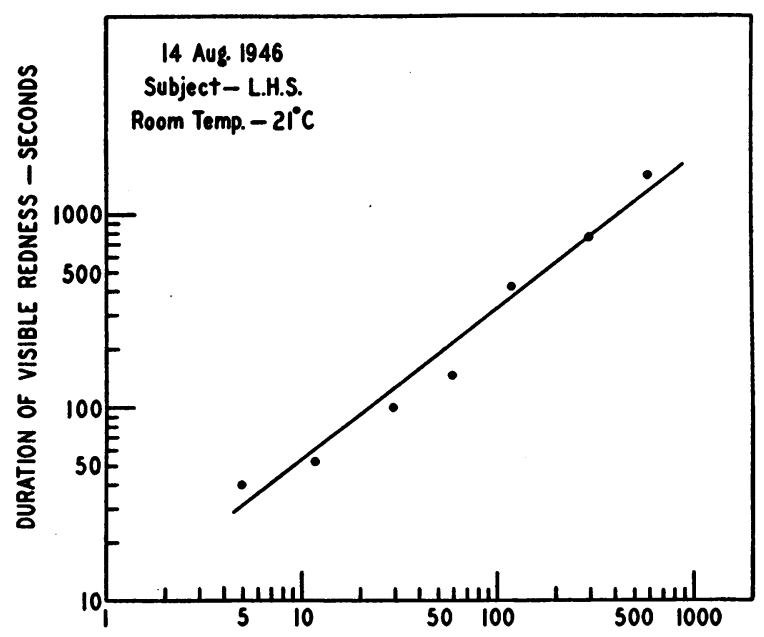

Fig. 1. Logarithmic Plot Showing Relation BetWEen Duration of Occlusion and Duration of Reactive Hyperemia, in One Subject

Similar relation was observed in 48 experiments on three subjects at room temperatures from $17^{\circ}$ to $37^{\circ} \mathrm{C}$. and with congesting pressures from 0 to $60 \mathrm{~cm}$. water.
Figure 1 shows that, in localized reactive hyperemia also, increasing the time of occlusion increased the duration of the local hyperemic response. With the arm at or below heart level reactive hyperemia was absent until the time of occlusion was increased to 5 seconds, which was therefore the "threshold" in this instance. Above this threshold visible reddening of the skin lasted from two to eight times as long as the preceding occlusion. This prolonged effect of local occlusion by pressure of the ring can be ascribed to several factors. (1) Because normal and hyperemic skin are adjacent to each other the contrast afforded by the ring of hyperemia is more accurate than comparison of one forearm with the other. (2) The ring not only arrests blood flow but, through external pressure, also evacuates blood from the minute vessel whereas the inflation of a cuff on the upper arm, as done by Lewis and Grant (9), leaves within all the minute vessels a certain amount of oxygenated blood and hence, for a given time of occlusion, produces less hypoxia than does the weighted ring. Of far less importance, but still conceivably contributory, may be (3) arrest of diffusion of atmospheric oxygen through the skin (Goldschmidt and McGlone, [10]) while compressed by the ring, and (4). transitory increase of vasoconstrictor tone due to pain produced when an occluding cuff is used (Abramson et al., [11]).

The relative accuracy of long and short applications of the ring under several experimental conditions showed that the briefer and repeated determinations of "threshold time" were more accurate and sensitive than the longer applications, e.g., 5 or 10 minutes. The latter, in fact, produced depressions in the skin which made accurate readings more difficult. Hence for the remaining studies only threshold values were determined. The close relation between duration of occlusion and duration of reactive hyperemia showed, however, that this local response is essentially similar to that described by Lewis and Grant (9) following the release of an occluding cuff on the upper arm.

\section{Effect of environmental and cutaneous temper- atures on reactive hyperemia}

Intensification of reactive hyperemia by warming the skin in a water bath was described by 


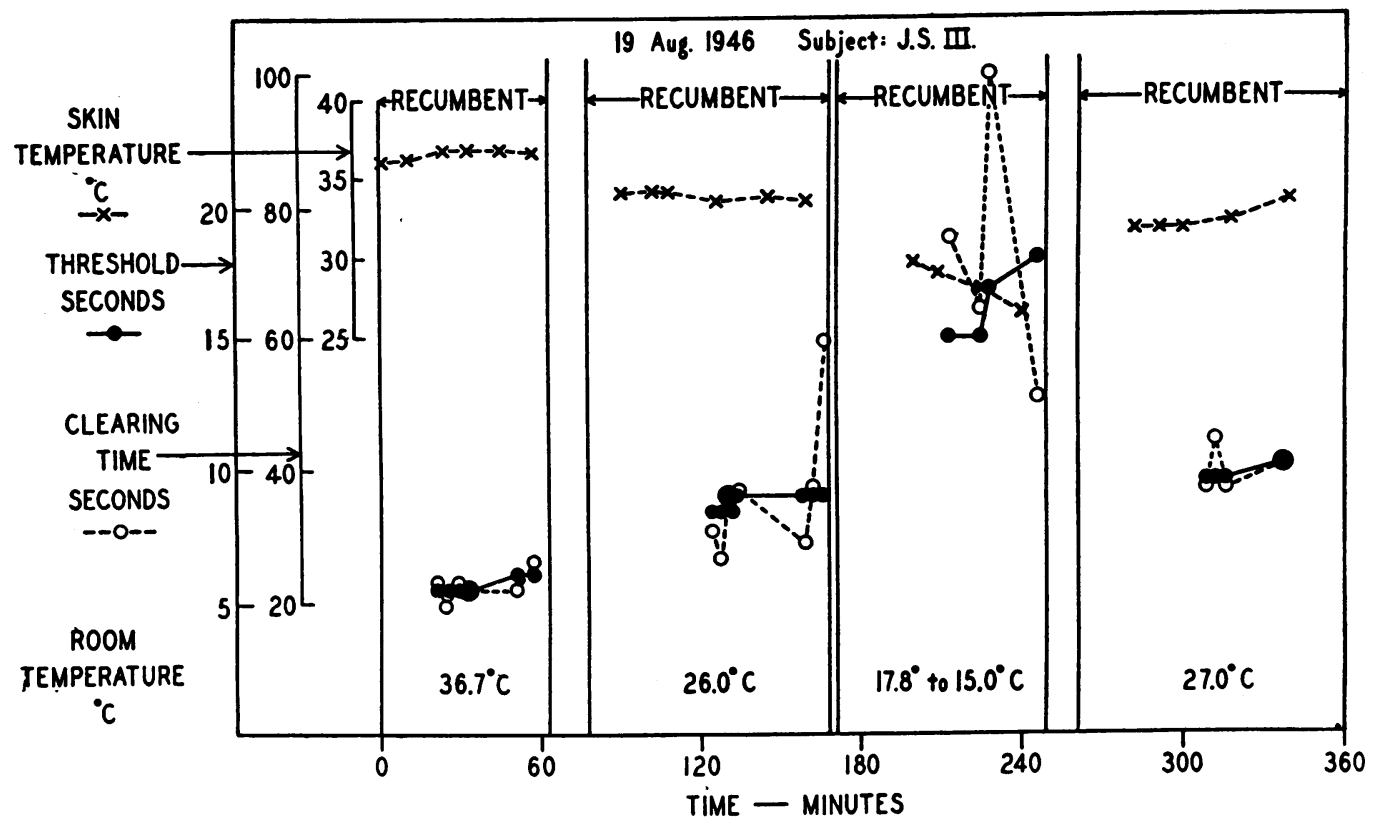

Fig. 2. Chart Showing Effects of Environmental Temperature on Threshold (Solid Dots and Lines) and on Clearing Time (Circles and Dotted Lines) of Reactive Hyperemia

Skin temperature is shown by crosses. Subject recumbent with forearm at heart level during observations but moving about between observations. Thermal junctions in this experiment covered with one layer of adhesive tape.

Lewis and Grant (9). This relation was defined more quantitatively by determining thresholds and clearing times at environmental temperatures ranging from $17^{\circ}$ to $37^{\circ} \mathrm{C}$. and skin temperatures ranging from $26^{\circ}$ to $37^{\circ} \mathrm{C}$. The results of a typical experiment are shown in Figure 2.

At zero time the subject, dressed only in shorts, had been recumbent for 30 minutes in the controlled temperature room at $36.7^{\circ} \mathrm{C}$. Thresholds and clearing times, skin temperatures and room temperatures were recorded for $\mathbf{3 0}$ or more minutes. The subject was then allowed to move about for about 10 minutes. The room temperature was lowered to $26.0^{\circ} \mathrm{C}$., the subject again lay down for 30 minutes and observations were made at this new temperature. In each experiment room temperatures of $37^{\circ}, 27^{\circ}$, and $17^{\circ} \mathrm{C}$. were used in ascending or descending order with a final observation at $27^{\circ} \mathrm{C}$. As indicated in Figure 2 threshold and clearing times became progressively longer as environmental temperature was reduced. Although observations on three male subjects, aged 22 to 33 years, yielded results entirely similar to those in Figure 2, charting threshold and clearing times against environmental temperature showed wide variations.

However, when threshold and clearing times were charted against skin temperature, the effect of tissue temperature on reactive hyperemia became much clearer as indicated in Figure 3 . Though not always evident in a single subject, the average curves indicate clearly that reducing skin temperature by $5^{\circ} \mathrm{C}$. from $37^{\circ}$ to $32^{\circ} \mathrm{C}$., increased average threshold and clearing times by 50 per cent or less, whereas a like reduction of $5^{\circ} \mathrm{C}$., but from $32^{\circ}$ to $27^{\circ} \mathrm{C}$., increased both threshold and clearing times three- or four-fold. Under "Discussion" reasons will be given for believing that at skin temperatures above $32^{\circ} \mathrm{C}$. reactive hyperemia is determined almost solely by accumulated metabolites, whereas at skin temperatures below $32^{\circ} \mathrm{C}$. the behavior of the $\mathrm{cu}-$ taneous vessels in reactive hyperemia depends upon the balance between centrally induced vasoconstrictor tone and the local and opposing vasodilator effect of metabolites. 


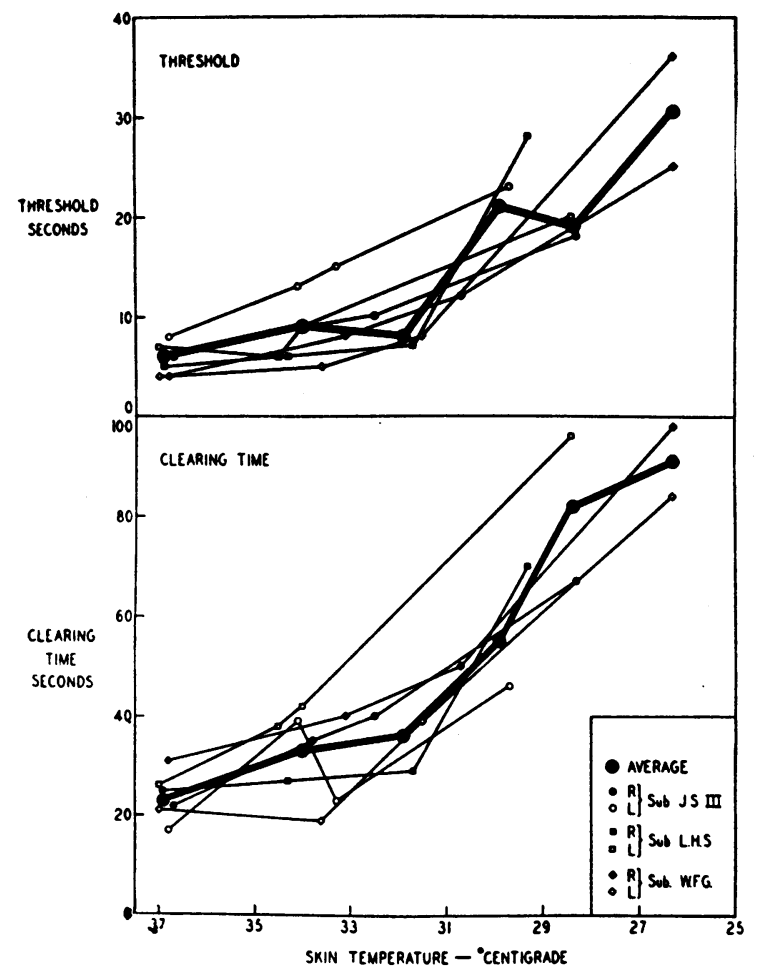

Fig. 3. Chart Showing the Relation Between Skin Temperature and Threshold (above) and Clearing Time (below)

Includes observations on three subjects made on right and left forearms independently by two observers. The five lines represent individual observations. The large dots and heavy lines indicate averages along both coordinates of all observations falling within each interval of $2^{\circ} \mathrm{C}$. from $37^{\circ}$ to $26^{\circ} \mathrm{C}$.

\section{Effect of increased venous pressure on re- active hyperemia}

It was also found that venous pressure had marked effects on both threshold and clearing time, i.e., on the ease with which visible and persistent reactive hyperemia could be produced. The results of a typical experiment are shown in Figure 4. At zero time the subject had been recumbent for 30 minutes, with the forearm at heart level. Threshold and clearing times having been relatively constant for 30 minutes, venous pressure was elevated suddenly to $40 \mathrm{~cm}$. $\mathrm{H}_{2} \mathrm{O}$. Threshold fell gradually over 5 to 20 minutes to one-fourth the control value and clearing time became, for a few readings, three times greater, finally stabilizing at about twice the control value.
While clearing time occasionally rose briefly to a peak as shown to the left in Figure 4, it was more usually elevated merely to a plateau, as shown in the middle and to the right in Figure 4. Results observed in seven subjects are summarized in Table I. Elevating venous pressure to $20 \mathrm{~cm}$. $\mathrm{H}_{2} \mathrm{O}$ lowered threshold in five of seven subjects and increased clearing time in all. Venous pressures of 30 or more $\mathrm{cm} . \mathrm{H}_{2} \mathrm{O}$ reduced threshold and raised clearing time in all subjects. On the average these effects became more conspicuous as venous pressure increased but in individual subjects this was not always the case (Table I).

Measurements of skin temperature demonstrated the slight cooling of the skin ordinarily found during venous congestion but these changes were far too small to explain the marked changes in reactive hyperemia. A more delicate differential thermopile was also used to detect changes in cutaneous blood flow. Congesting pressures of 20 and $30 \mathrm{~cm}$. $\mathrm{H}_{2} \mathrm{O}$ reduced blood flow by a barely measurable amount. This reduction seemed far too small to explain the markedly reduced threshold and increased clearing time, though the action of gradually accumulating metabolites cannot be excluded entirely.

Subsequent observations on the effects of position and of external pressure led to the conclusion that the appearance and duration of visible reactive hyperemia are greatly modified by the degree

TABLE I

Effect of venous pressure on visible reactive hyperemia

\begin{tabular}{|c|c|c|c|c|c|c|}
\hline \multirow{2}{*}{ Venous pressure } & \multicolumn{3}{|c|}{$\begin{array}{l}\text { Change of threshold } \\
\text { per cent of control }\end{array}$} & \multicolumn{3}{|c|}{$\begin{array}{l}\text { Change of clearing time } \\
\text { per cent of control }\end{array}$} \\
\hline & $\begin{array}{c}20 \\
\mathrm{~cm} . \\
\mathrm{H}_{2} \mathrm{O}\end{array}$ & $\begin{array}{c}30 \\
\mathrm{~cm} . \\
\mathrm{H}_{2} \mathrm{O}\end{array}$ & $\begin{array}{c}\mathbf{4 0} \\
\mathrm{cm} . \\
\mathrm{H}_{2} \mathrm{O}\end{array}$ & $\begin{array}{c}20 \\
\mathrm{~cm} . \\
\mathrm{H}_{2} \mathrm{O}\end{array}$ & $\begin{array}{c}30 \\
\mathrm{~cm} . \\
\mathrm{H}_{2} \mathrm{O}\end{array}$ & $\begin{array}{c}\mathbf{4 0} \\
\mathrm{cm} . \\
\mathrm{H}_{2} \mathrm{O}\end{array}$ \\
\hline $\begin{array}{l}\text { Subject } \\
\text { DiP. } \\
\text { A. C. B. } \\
\text { A. C. B. } \\
\text { J. S., III } \\
\text { J. S., III } \\
\text { W. F. G. } \\
\text { L. H. S. }\end{array}$ & $\begin{array}{r}\text { per } \\
\text { cent } \\
\\
0 \\
-44 \\
0 \\
-42 \\
-40 \\
-25 \\
-58\end{array}$ & $\begin{array}{l}\text { per } \\
\text { cent } \\
-38 \\
-61 \\
-20 \\
-39 \\
-40 \\
-30 \\
-43\end{array}$ & $\begin{array}{c}\text { per } \\
\text { cent } \\
\\
-80 \\
-74 \\
-20 \\
-44 \\
-40 \\
-40 \\
-72\end{array}$ & $\begin{array}{l}\text { per } \\
\text { cent } \\
+33 \\
+35 \\
+55 \\
+50 \\
+78 \\
+67 \\
+22 \\
+15\end{array}$ & $\begin{array}{r}\text { per } \\
\text { cent } \\
\\
+50 \\
+110 \\
+66 \\
+68 \\
+46 \\
+41 \\
+87\end{array}$ & $\begin{array}{c}\text { per } \\
\text { cent } \\
\\
+16 \\
+140 \\
+78 \\
+43 \\
+69 \\
+67 \\
+107\end{array}$ \\
\hline $\begin{array}{l}\text { Average change, } \\
\text { per cent of } \\
\text { control }\end{array}$ & -30 & -39 & -53 & +46 & +67 & +74 \\
\hline
\end{tabular}




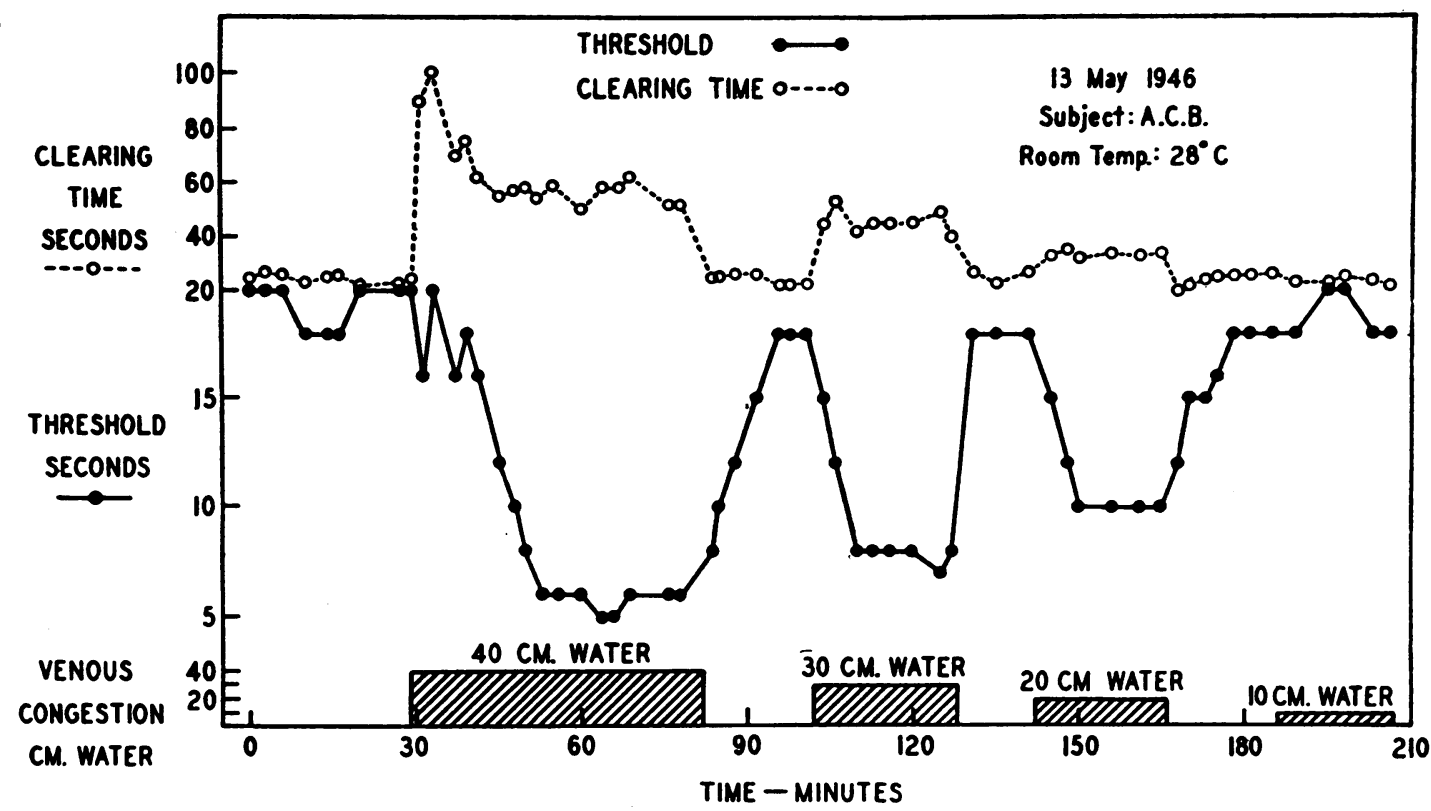

Fig. 4. Chart Showing Effect of Venous Pressure on the Threshold and Clearing Time of REACTIVE HYPEREMIA

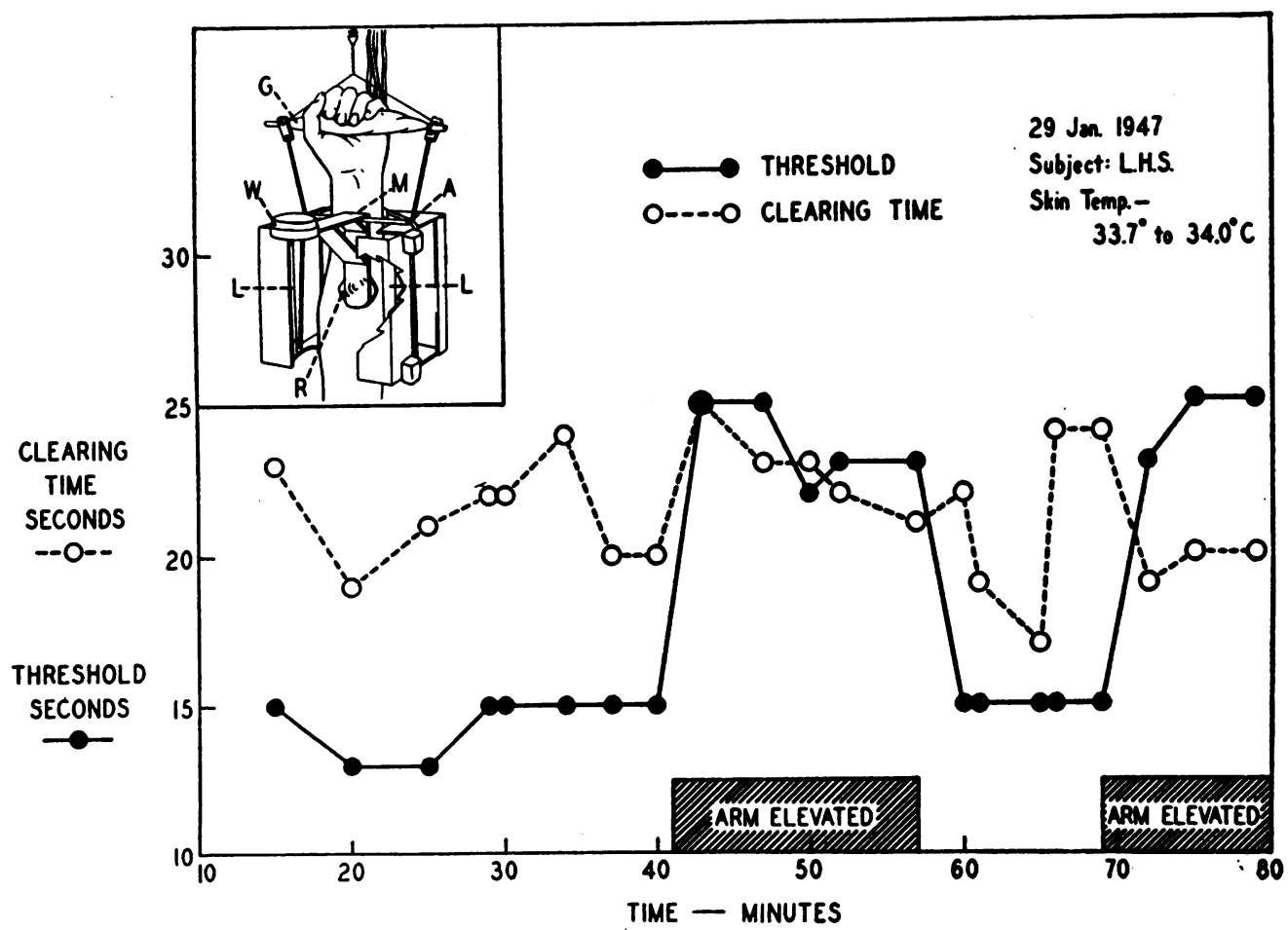

Fig. 5. Chart Showing Effect of Elevating the Forearm above Heart Level

At zero time subject was recumbent with forearm at side. Forearm elevated as indicated on abscissa, placing test area 30 to $40 \mathrm{~cm}$. above the angle of Louis. In elevated position thresholds and clearing times were determined by means of apparatus shown by inset. 
to which the subpapillary venous plexus is distended prior to, and during, reactive hyperemia.

\section{Effect of elevating the forearm (and reducing venous pressure) on visible reactive hyperemia}

When the volar surface of the forearm was horizontal at heart level or below, the occluding ring could simply be laid on the skin. To test the effect of lowering venous pressure by raising the forearm well above heart level, it was necessary to mount the plastic ring on the right-angled holder shown by the inset of Figure 5 .

With the forearm suspended vertically from the handgrip " $G$," the right-angled mounting " $M$ " moved freely on the axle "A." When this mounting rested firmly against the skin, the 500-gm. weight "W" pressed the ring " $R$ " against the skin of the vertically placed forearm with a pressure of about $73 \mathrm{~mm}$. $\mathrm{Hg}$ just as the simple weight and ring did in the horizontal forearm. Two small fluorescent lamps "L" provided uniform lighting in whatever position the forearm might be.

A typical experiment is shown in Figure 5. At heart level, threshold was 13 to 15 seconds and clearing time averaged 22 seconds. Elevating the forearm as far as possible above heart level raised threshold promptly and conspicuously but did not change clearing time significantly. Conversely, lowering the forearm to heart level returned threshold again to the control level. Table II summarizes the results of similar experiments on three subjects. To produce visible hyperemia in the elevated forearm required an occlusion last-

TABLE II

Effect of elevating the forearm on visible reactive hyperemia

\begin{tabular}{l|c|c|c|c|c|c}
\hline \hline & \multicolumn{3}{|c|}{ Threshold } & \multicolumn{3}{c}{ Clearing time } \\
\cline { 2 - 6 } Subject & $\begin{array}{c}\text { Forearm } \\
\text { hori- } \\
\text { zontal }\end{array}$ & $\begin{array}{c}\text { Forearm } \\
\text { ele- } \\
\text { vated }\end{array}$ & Change & $\begin{array}{c}\text { Forearm } \\
\text { hori- } \\
\text { zontal }\end{array}$ & $\begin{array}{c}\text { Forearm } \\
\text { ele- } \\
\text { vated }\end{array}$ & Change \\
\cline { 2 - 6 } & sec. & sec. & per cent & sec. & sec. & per cent \\
& 11 & 21 & +91 & 26 & 28 & +8 \\
J. S., III & 11 & 20 & +67 & 21 & 24 & +14 \\
J. S., III & 12 & 16 & +45 & 30 & 23 & -23 \\
L. H. S. & 11 & 17 & +55 & 25 & 24 & -4 \\
L. H. S. & 11 & 15 & +60 & 22 & 20 & -9 \\
L. H. S. & 15 & 24 & +67 & 31 & 25 & -19 \\
W. F. G. G. & 12 & 20 & +80 & 41 & 26 & -37 \\
W. F. G. & 10 & 18 & +80 & & -10 \\
\hline Average change, per cent & +66 & & & \\
\hline
\end{tabular}

ing 66 per cent longer than in the horizontal forearm. Despite this longer occlusion, however, the clearing time was not significantly changed; i.e., the hyperemia remained visible for the usual period of 20 to 40 seconds in both positions. Changes in skin temperature were again too slight to explain the observed changes in threshold.

\section{Effect of external pressure on reactive hyper- emia}

The changes in visible reactive hyperemia produced by venous congestion and change of position suggested that the state of the subpapillary venous plexus, i.e., whether distended or collapsed, influences the intensity of skin color in reactive hyperemia as it does normal skin color (Lewis, [12]). Hence external pressure was used to collapse the subpapillary venous plexus while reactive hyperemia was induced.

The forearm, supported at heart level, was inserted into a transparent celluloid chamber through a thin rubber diaphragm which fitted the forarm snugly but did not congest it. While pressure on the skin was elevated to the desired level (20, 40 , or $60 \mathrm{~cm} . \mathrm{H}_{2} \mathrm{O}$ ) the weighted ring could be applied to, and removed from, the skin by hanging it from a rod which entered the distal end of the chamber through a flexible rubber stopper. The time of occlusion being varied, threshold and clearing times were observed through the transparent celluloid.

A typical observation is shown in Figure 6. Long rest periods were interpolated at intervals merely to avoid the discomfort which developed when the forearm was immobilized at heart level in the chamber for periods exceeding 45 minutes. Increasing the external pressure on the skin and its blood vessels increased threshold but did not change clearing time. Table III summarizes the results of three observations on different subjects. External pressures of 20,40 and $60 \mathrm{~cm} . \mathrm{H}_{2} \mathrm{O}$ increased threshold by 53, 78 and 129 per cent, respectively, whereas changes in clearing time were irregular and not significant. Skin temperatures were measured throughout; changes were too small to affect threshold. It appears that visible reactive hyperemia is more difficult to elicit both when external pressure on the skin is increased 

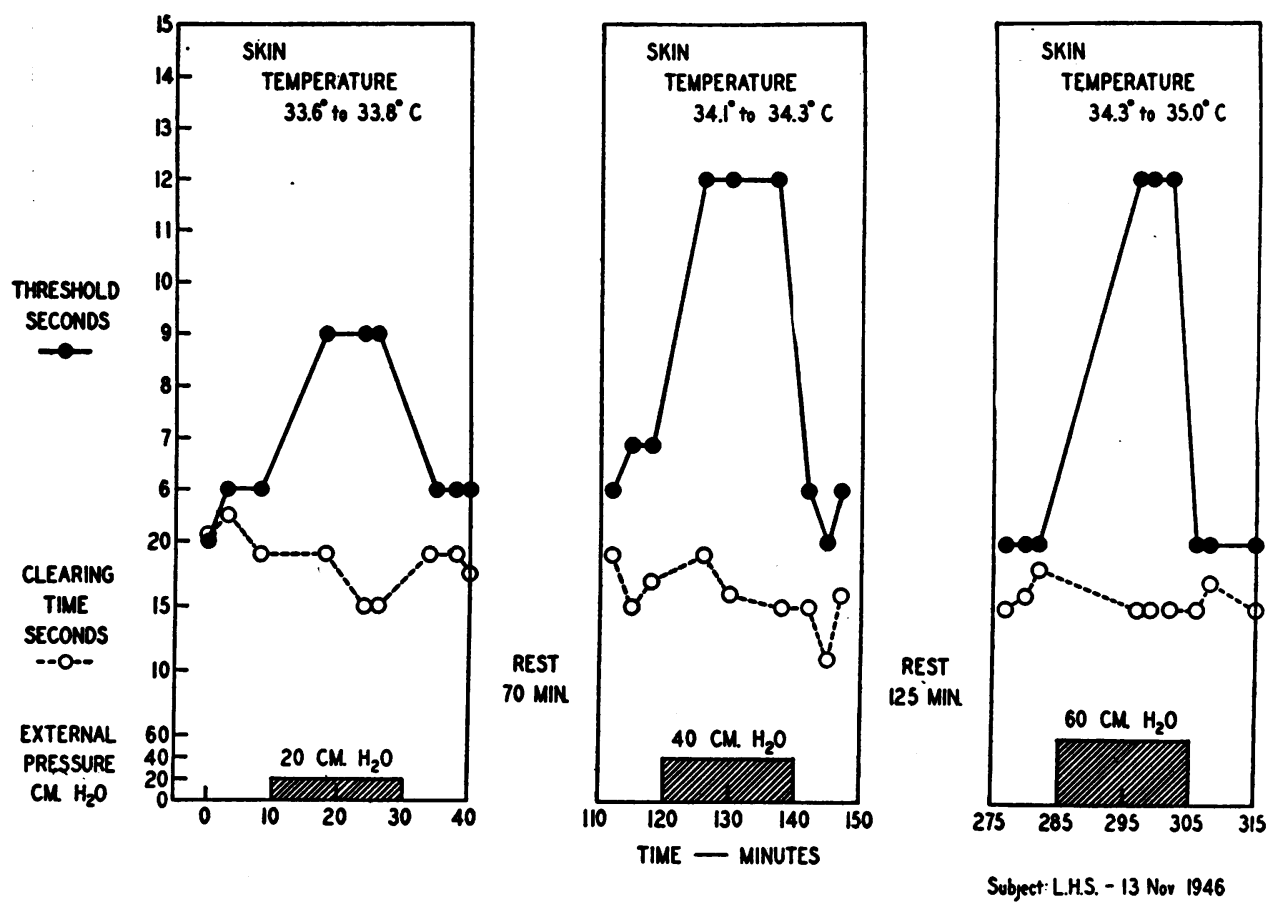

Fig. 6. Chart Showing Effect of External Pressure on Threshold and Clearing Times

and when venous pressure is reduced somewhat by raising the forearm (Figure 5 and Table II). Decreased filling of the cutaneous subpapillary venous plexus is common to these two procedures and reduces markedly the visibility of the hyperemia which follows very brief arterial occlusion.

\section{Effect of epinephrine iontophoresis on re- active hyperemia}

The disproportionately increased threshold observed when room and skin temperatures were reduced (Figure 3 ) suggested that vasoconstrictor tone interfered with the dilatation otherwise

TABLE III

Effect of external pressure on reactive hyperemia

\begin{tabular}{c|c|c|c|c|c|c}
\hline \multirow{2}{*}{$\begin{array}{c}\text { Pressure, cm. of } \\
\text { water }\end{array}$} & \multicolumn{3}{|c|}{ Change in threshold } & \multicolumn{3}{|c}{ Change in clearing time } \\
\cline { 2 - 7 } & 20 & 40 & 60 & 20 & 40 & 60 \\
\hline & $\begin{array}{c}\text { per } \\
\text { cent }\end{array}$ & $\begin{array}{c}\text { per } \\
\text { cent }\end{array}$ & $\begin{array}{c}\text { per } \\
\text { cent }\end{array}$ & $\begin{array}{c}\text { per } \\
\text { cent }\end{array}$ & $\begin{array}{c}\text { per } \\
\text { cent }\end{array}$ & $\begin{array}{c}\text { per } \\
\text { cent }\end{array}$ \\
$\begin{array}{c}\text { Subject } \\
\text { W. F. G. } \\
\text { L. H. S. } \\
\text { J. S., III }\end{array}$ & +30 & +109 & +86 & +26 & +14 & +62 \\
+50 & +82 & +150 & -23 & -4 & $\frac{11}{-11}$ \\
+80 & +44 & +150 & +24 & -12 & +15 \\
\hline $\begin{array}{c}\text { Average } \\
\text { per cent }\end{array}$ & +53 & +78 & +129 & +9 & 0 & +22 \\
\hline
\end{tabular}

produced by metabolites. This could not be concluded definitely, however, because of the concomitant reduction of metabolism in the cooled skin. To produce an increase in the tone of the minute vessels uncomplicated by other factors, epinephrine hydrochloride was introduced into the skin by iontophoresis while reactive hyperemia was tested repeatedly.

Figure 7 shows the effect of introducing $1: 10$,000 epinephrine hydrochloride for 10 minutes from a filter paper electrode $40 \mathrm{sq} . \mathrm{cm}$. in area at 250 microamperes (62 microamperes per sq. cm.). Spotty blanching appeared at the anode and it was impossible to obtain a threshold reactive hyperemia even though circulation was stopped for 2 minutes, or six times the control threshold of 18 seconds. Reactive hyperemia was detected first about 11 minutes after the end of iontophoresis and then it required 2 minutes' occlusion. Clearing times were correspondingly prolonged. Reactive hyperemia returned to normal about 50 minutes after the end of iontophoresis. Results similar in every way to Figure 7 were obtained in three subjects.

In a larger series of subjects the effects of lower concentrations of epinephrine were studied 


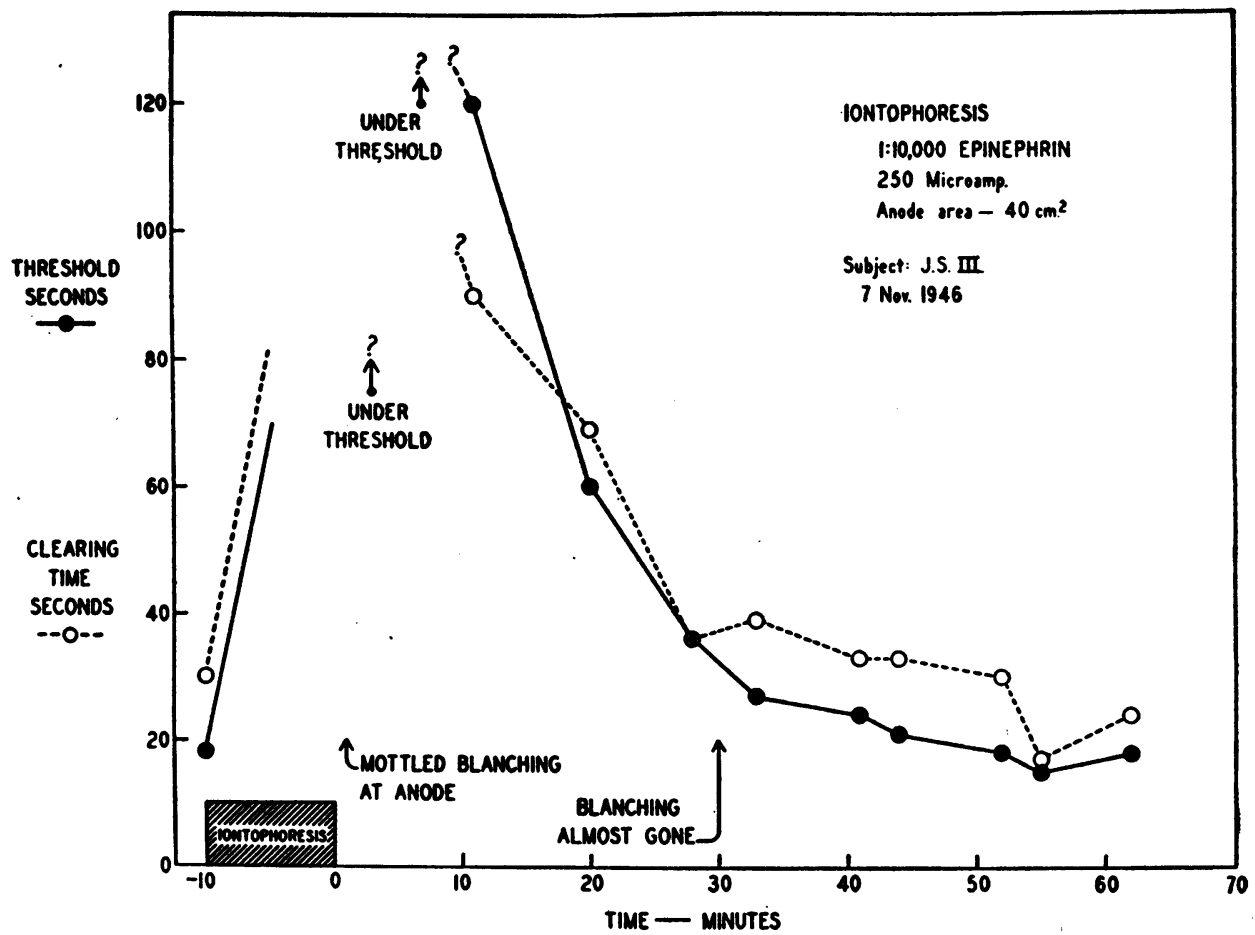

Fig. 7. Chart Showing Increase of Threshold and Clearing Time Produced by Prior IONTOPHORESIS OF EPINEPHRINE

as shown in Table IV. Iontophoresis was here limited to 30 seconds with current strength of 36 microamperes per sq. cm. ${ }^{4}$. Even though the current was lower and the duration of iontophoresis was briefer, $1: 10,000$ epinephrine elevated threshold in all subjects by an average of over 200 per

TABLE IV

Effect of epinephrine iontophoresis using 1:10,000 to $1: 1,000,000$ solutions

\begin{tabular}{|c|c|c|c|c|c|}
\hline $\begin{array}{l}\text { Concentra- } \\
\text { tion of } \\
\text { epinephrine }\end{array}$ & $\begin{array}{c}\text { Num- } \\
\text { ber } \\
\text { of } \\
\text { sub- } \\
\text { jects }\end{array}$ & $\begin{array}{l}\text { Total } \\
\text { num- } \\
\text { ber of } \\
\text { experi- } \\
\text { ments }\end{array}$ & $\begin{array}{c}\text { Number of experi- } \\
\text { ments showing } \\
\text { increase of } \\
\text { threshold }\end{array}$ & $\begin{array}{c}\text { Average } \\
\text { increase } \\
\text { in } \\
\text { thresh- } \\
\text { old* }\end{array}$ & $\begin{array}{l}\text { Average } \\
\text { increase } \\
\text { in } \\
\text { clearing } \\
\text { time* }\end{array}$ \\
\hline $\begin{array}{l}1: 10,000 \\
1: 50,000 \\
1: 100,000 \\
1: 500,000 \\
1: 1,000,000\end{array}$ & $\begin{array}{r}9 \\
11 \\
11 \\
9 \\
5\end{array}$ & $\begin{array}{r}19 \\
19 \\
21 \\
12 \\
5\end{array}$ & $\begin{array}{c}19(100 \text { per cent }) \\
16(84 \text { per cent }) \\
17 \text { (81 per cent }) \\
7 \text { (58 per cent }) \\
1(20 \text { per cent })\end{array}$ & $\begin{array}{c}\text { per cent } \\
259 \\
171 \\
92 \\
54 \\
5\end{array}$ & $\begin{array}{c}\text { per cent } \\
>87 \dagger \\
>69 \dagger \\
15 \\
17 \\
0\end{array}$ \\
\hline
\end{tabular}

* The per cent increase was calculated by dividing the sum of the increases by the total number of experiments. Thus with 1:1,000,000 epinephrine, one subject of the five showed a rise of 25 per cent, the others none. The average rise was 5 per cent.

$\dagger$ Actual value greater than recorded because procedure did not always allow time for reading full clearing time.

4 These observations were made by J. R. DiPalma at the Long Island College of Medicine. cent. A significant effect was observed with concentrations down to $1: 500,000$. With these lower concentrations, however, considerable variability was observed in different subjects and also in the same subject from day to day, presumably owing to unequal penetration of epinephrine through the skin.

Control observations showed that the simple passage of current through the skin via electrodes soaked in distilled water or 0.9 per cent $\mathrm{NaCl}$ solution either had no effect on threshold or, by producing redness of the skin (13), made accurate readings impossible. Nevertheless, epinephrine in sufficient strength always produced blanching and elevated both threshold and clearing times. It seems certain that these changes were due to the constrictor action of epinephrine which reduced the ability of the minute vessels to respond normally by dilatation to the metabolites accumulated when circulation was occluded briefly.

\section{DISCUSSION}

The close relation between duration of occlusion and duration of visible redness (Figure 1) indi- 
cates that the reactive hyperemia produced by local compression of the skin resembles the more generalized reactive hyperemia produced by Lewis and Grant (9) when circulation to the whole forearm was occluded by means of a pneumatic cuff on the arm. Both appear to be due to the local accumulation of metabolites but the greater sensitivity of localized reactive hyperemia made it possible to identify secondary factors which enhance or diminish the visible response.

The temperature of the skin is known to affect the degree of vasodilatation produced by arresting the circulation for a given time. Lewis and Grant (9) observed, in a limb at $36^{\circ} \mathrm{C}$., that plethysmographically recognizable reactive hyperemia occurred after occlusions as brief as $\mathbf{5}$ seconds. At lower temperatures they found longer occlusions were necessary but no specific times were stated. Local reactive hyperemia responds in a similar manner to changes in temperature. Thus when skin temperature was $37^{\circ} \mathrm{C}$. the average threshold (Figure 3) was only 6 seconds; at $27^{\circ} \mathrm{C}$. threshold was about 30 seconds, a five-fold increase for a difference of $10^{\circ} \mathrm{C}$. Average clearing time, i.e., the time required for disappearance of the flush, also increased five-fold when the skin was cooled $10^{\circ} \mathrm{C}$.

This change was not uniform, however, throughout the whole range of $27^{\circ}$ to $37^{\circ} \mathrm{C}$. From $37^{\circ}$ to $32^{\circ} \mathrm{C}$. the average rate of change was low, amounting to a doubling of threshold or clearing time for a lowering of skin temperature by $10^{\circ} \mathrm{C}$. From $32^{\circ} \mathrm{C}$. to $27^{\circ} \mathrm{C}$. the average rate of change was much greater, i.e., at the rate of a five- to eight-fold change for a change of $10^{\circ} \mathrm{C}$. in skin temperature.

As Lewis and Grant (9) mention, the effect of tissue temperature on reactive hyperemia suggests of itself that dilatation depends on the metabolic rate of the tissue. A rise of $10^{\circ} \mathrm{C}$. usually increases the rate of metabolic processes two- or three-fold. For extremities sympathectomized six months earlier, Freeman (14) found that blood flow plotted against bath temperature by the Arrhenius equation yielded a straight line. The slope of this line indicates a 2.5 -fold change of blood flow for a temperature difference of $10^{\circ} \mathrm{C}$. In local reactive hyperemia, threshold and clearing time also showed changes of this order when skin temperature was above $32^{\circ} \mathrm{C}$.

Below $32^{\circ} \mathrm{C}$., however, the rate of change in threshold and clearing time with change of temperature became much greater. In these observations skin temperatures at the critical point, approximately $32^{\circ} \mathrm{C}$., corresponded to an average air temperature of $25^{\circ} \mathrm{C}$. Both these temperatures agree remarkably well with those at which Ferris et al. (15) observed an abrupt increase of blood flow in the hand, apparently due to a freeing of the cutaneous vessels from vasoconstrictor impulses when conservation of heat was no longer required by the thermoregulatory mechanism. On this basis it is suggested that the slow increase in threshold, as skin temperature fell from $37^{\circ}$ to $32^{\circ} \mathrm{C}$., can be explained by a slower accumulation of metabolites. The more rapid increase of threshold as skin temperature fell from $32^{\circ}$ to $27^{\circ}$ C. was then probably due $(a)$ to continued slowing of metabolite accumulation, and in addition (b) to increasing vasoconstrictor tone. The latter, by resisting vasodilatation, required a larger total accumulation of metabolites, and hence a longer occlusion time or threshold to produce a visible reactive hyperemia, as well as a longer period of hyperemia, i.e., clearing time, to remove those metabolites.

Venous pressure proved to be another extremely important modifying factor. When the forearm was kept at heart level, increasing venous pressure (Figure 4) reduced threshold and prolonged the clearing time. Dependency of the forearm had the same general effect. On the contrary, elevating the forearm (Figure 5) increased threshold time definitely above that observed at heart level but had little effect on clearing time. The changes were too great to explain, on the basis of change in temperature, tone of minute vessels or those small changes in blood flow that mild venous congestion or change in position might produce.

Skin color is largely determined by the amount, and the oxygenation, of the blood in the subpapillary venous plexus (12). Thus the depth of skin color of a whole extremity is less when the extremity is held above heart level than when it hangs dependent. An elevation of venous pressure can presumably affect the visibility of a given 
hyperemia in at least two ways: (1) By increasing internal pressure in the subpapillary venous plexus, it may make those vessels more easily dilatable by smaller accumulations of vasodilator metabolites and hence reduce the duration of occlusion (or threshold) necessary to produce a visible hyperemia. (2) By widening passively the vessels which comprise the subpapillary venous plexus, an increased venous pressure may make a given hyperemia more easily visible because increments of inrushing arterial blood remain in a given area of skin in greater amount and for a longer time and so change skin color more distinctly. Other things remaining constant both factors would not only tend to decrease threshold but also to prolong clearing time.

Elevating the forearm, by lowering venous pressure, should act in the opposite direction, i.e., increase threshold because internal tension is less and because greater arterial inflow into the collapsed plexus would be required to produce a visible hyperemia. A similar prolongation of clearing time need not occur, however, because the subpapillary venous plexus tends to empty itself rapidly when the extremity is elevated. The converse also appears to hold. When the subpapillary venous plexus was collapsed by applying external pressure to the forearm, threshold rose apparently because external pressure made dilatation more difficult as well as less easily visible. Clearing time did not change, however, and the effect was similar to that observed when the forearm was simply elevated. In this connection it is noteworthy that as the forearm is progressively elevated, venous pressure does not fall to zero but to a plateau between 2 and $5 \mathrm{~cm} . \mathrm{H}_{2} \mathrm{O}(16,17)$. Correspondingly, the changes in threshold produced by elevating the forearm were limited and smaller than those that could be produced by external pressure. Though clearing time was increased by venous congestion, both elevation and external pressure had no significant effect. From this it seems probable that small changes in venous pressure modified the visibility of cutaneous reactive hyperemia by mechanical effects on the subpapillary venous plexus rather than by changes of arterial blood flow.

The effect of increased tone of the minute vessels, while suggested by the studies on temperature, was demonstrated more clearly by epineph- rine iontophoresis (Figure 7). Temperature, venous pressure and position being constant, epinephrine increased both threshold and clearing time, the former more conspicuously. These effects were very marked as long as visible blanching persisted, but in slighter degree persisted beyond the period of gross blanching.

Reactive hyperemia is obviously not a simple reaction. Though fundamentally due to the accumulation of vasodilator metabolites, the visible redness of normal skin can be affected secondarily by several other factors. Among these are $(a)$ the temperature of the skin which determines the rate at which metabolites accumulate during an occlusion of the circulation; $(b)$ venous pressure and position of the extremity which modify the effect of a given occlusion by mechanical effects on the subpapillary venous plexus and thereby on the visibility of a given hyperemia; and $(c)$ the tone of the minute vessels, either of neurogenic origin, as in cold, or of local chemical origin as in epinephrine iontophoresis. Because local reactive hyperemia is affected markedly by modifying vascular tone, it can be used to detect cutaneous vasoconstriction, providing skin temperature and venous pressure in the forearm are known to be constant. The results observed with this method during exhausting exercise and other circulatory stresses are reported in another paper (6).

\section{SUMMARY}

The factors affecting cutaneous reactive hyperemia in man were studied semiquantitatively by means of a previously described method in which blood flow in the skin was stopped locally by applying a weighted ring to the volar surface of the forearm. The end points used were $(a)$ the duration of occlusion required to produce a clearly visible ring of hyperemia (threshold) and $(b)$ the time required for skin color to return to normal (clearing time).

Lowering of tissue temperature produced a moderate increase of threshold and clearing time between $37^{\circ}$ and $32^{\circ} \mathrm{C}$. and a very conspicuous increase of both between $32^{\circ}$ and $27^{\circ} \mathrm{C}$. Reasons are given for ascribing the former to the action of metabolites predominantly, and the latter to heightened vasoconstrictor tone acting against the dilator effect of metabolites. 
Increasing venous pressure by congestion or by dependency of the forearm lowered threshold and increased clearing time. Elevation of the forearm or application of pressure to the surface of the forearm increased threshold but did not affect clearing time. It appears that these factors act by their mechanical effects on the subpapillary venous plexus and consequently on the visibility of a given increase of arterial blood flow.

Iontophoresis of epinephrine, by increasing the tone of the minute vessels, increased both threshold and clearing time conspicuously.

If venous pressure and skin temperature are kept constant local reactive hyperemia can be used to detect rapid changes in the tone of the minute vessels of the skin in man.

\section{ACKNOWLEDGMENT}

The authors are indebted to Dr. Eugene M. Landis for help and criticism throughout the planning, execution and description of these studies.

\section{BIBLIOGRAPHY}

1. Pickering, G. W., On the clinical recognition of structural disease of the peripheral vessels. Brit. M. J., 1933, 2, 1106.

2. DiPalma, J. R., Muss, J., and Foster, F. I., A reactive hyperemia ring test in the study, evaluation, and prognosis of pedal lesions caused by arteriosclerosis obliterans and arterial embolism. Am. Heart J., 1942, 24, 345.

3. DiPalma, J. R., The circulation in the skin in the shock syndrome; comparison of simple prognostic features of clinical value. J. A. M. A., 1943, 123, 684.

4. Herzog, F., Messung der reactiven Erwärmung der Haut zur Funktionsprüfung der Arteriolen. Klin. Wschnschr., 1941, 20, 20.
5. von Marsovsky, P., Über die Funktion der Arteriolen bei dekompensierten Herzkrankung. Ztschr. f. Kreislaufforsch., 1942, 34, 446.

6. Barger, A. C., Greenwood W. F., DiPalma, J. R., Stokes, J., and Smith, L H. To be published.

7. DiPalma, J. R., Reynolds, S. M. R., and Foster, F. I., Quantitative measurement of reactive hyperemia in the human skin; individual and seasonal variations. Am. Heart J., 1942, 23, 377.

8. McLennan, C. E., McLennan, M. T., and Landis, E. M., The effect of external pressure on the vascular volume of the forearm and its relation to capillary blood pressure and venous pressure. $\mathrm{J}$. Clin. Invest., 1942, 21, 319.

9. Lewis, T., and Grant, R., Reactive hyperemia in man. Heart, 1925, 12, 73.

10. Goldschmidt, S., and McGlone, B., Oxygen absorption through the skin. Effect upon the vascular reactions to stasis and histamine. Proc. Soc. Exper. Biol. \& Med., 1932, 29, 827.

11. Abramson, D. L., Katzenstein, K. H., and Ferris, E. B., Jr., Observations on reactive hyperemia in various portions of the extremities. Am. Heart J., 1941, 22, 329.

12. Lewis, T., Blood Vessels of Human Skin and Their Responses. Shaw \& Sons, London, 1927.

13. Ebbecke, U., Uber electrische Hautreizung. Pflüger's Arch. f. d. ges. Physiologie, 1922, 195, 300.

14. Freeman, N. E., The effect of temperature on the rate of blood flow in the normal and in the sympathectomized hand. Am. J. Physiol., 1935, 113, 384.

15. Ferris, B. G., Jr., Forster, R. E., II, Pillion, E. L., and Christensen, W. R., Control of peripheral blood flow; responses in the human hand when extremities are warmed. Am. J. Physiol., 1947, 150, 304.

16. Carrier, E. B., and Rehberg, P. B., Capillary and venous pressure in man. Skandinav. Arch. f. Physiol., 1923, 44, 20.

17. Ryder, H. W., Molle, W. E., and Ferris, E. B., Jr., The influence of the collapsibility of veins on venous pressure, including new procedure for measuring tissue pressure. J. Clin. Invest., 1944, 23, 333. 